\title{
Phloem Metabolites of Prunus Sp. Rather than Infection with Candidatus Phytoplasma Prunorum Influence Feeding Behavior of Cacopsylla pruni Nymphs
}

\author{
Jannicke Gallinger ${ }^{1,2}$ • Jürgen Gross ${ }^{1,2}$ (DD \\ Received: 11 November 2019 / Revised: 11 December 2019 / Accepted: 8 January 2020 / Published online: 22 January 2020 \\ (C) The Author(s) 2020
}

\begin{abstract}
Phytoplasmas are specialized small bacteria restricted to the phloem tissue and spread by hemipterans feeding on plant sieve tube elements. As for many other plant pathogens, it is known that phytoplasmas alter the chemistry of their hosts. Most research on phytoplasma-plant interactions focused on the induction of plant volatiles and phytohormones. Little is known about the influence of phytoplasma infections on the nutritional composition of phloem and consequences on vector behavior and development. The plum psyllid Cacopsylla pruni transmits 'Candidatus Phytoplasma prunorum', the causing agent of European Stone Fruit Yellows (ESFY). While several Prunus species are susceptible for psyllid feeding, they show different responses to the pathogen. We studied the possible modulation of plant-insect interactions by bacteria-induced changes in phloem sap chemistry. Therefore, we sampled phloem sap from phytoplasma-infected and non-infected Prunus persica and Prunus insititia plants, which differ in their susceptibility to ESFY and psyllid feeding. Furthermore, the feeding behavior and development of $C$. pruni nymphs was compared on infected and non-infected $P$. persica and $P$. insititia plants. Phytoplasma infection did not affect phloem consumption by $C$. pruni nymphs nor their development time. In contrast, the study revealed significant differences between $P$. insititia and P. persica in terms of both phloem chemistry and feeding behavior of $C$. pruni nymphs. Phloem feeding phases were four times longer on P. insititia than on P. persica, resulting in a decreased development time and higher mortality of vector insects on $P$. persica plants. These findings explain the low infestation rates of peach cultivars with plum psyllids commonly found in field surveys.
\end{abstract}

Keywords Plant-insect interaction · European stone fruit yellows · Vector development $\cdot$ Phytobiome $\cdot$ Phloem composition · Electropenetrography $\cdot$ Phytoplasma

\section{Introduction}

Phytoplasmas are phloem-restricted plant pathogenic bacteria, causing severe diseases in different plant species. Many of these phytoplasma-induced diseases affect agricultural crops (Bertaccini et al. 2014), resulting in high economic losses in

Electronic supplementary material The online version of this article (https://doi.org/10.1007/s10886-020-01148-8) contains supplementary material, which is available to authorized users.

Jürgen Gross

juergen.gross@julius-kuehn.de

1 Laboratory of Applied Chemical Ecology, Institute for Plant Protection in Fruit Crops and Viticulture, Federal Research Centre for Cultivated Plants, Julius Kühn-Institut, Dossenheim, Germany

2 Plant Chemical Ecology, Technical University of Darmstadt, Schnittspahnstr. 4, 64287 Darmstadt, Germany crop production all over the world (Smith 1997). For example, the causal agent of the European stone fruit yellows (ESFY), 'Candidatus Phytoplasma prunorum', infects different species of the genus Prunus. Infected trees suffer from severe symptoms, yield poorly, and exhibit dieback and decline (Kison and Seemüller 2001; Marcone et al. 1996; Nečas et al. 2017). Several Prunus species are susceptible to ' $\mathrm{Ca}$. P. prunorum' but vary in degree of symptom expression (Carraro et al. 2004a; Jarausch et al. 2000). Peaches, apricots and Japanese plums are severely affected (Kison and Seemüller, 2001; Torres et al. 2004), whereas Prunus domestica, Prunus cerasifera and Prunus insititia are found to be less affected (Kison and Seemüller 2001). Differences in response to ESFY infections also occur between cultivars within species (Koncz et al. 2017; Marcone et al. 1996; Richter 2002). Diverse symptoms are known to be associated with phytoplasma diseases. Besides structural changes of the vascular system, such as callose deposition, phloem necrosis, and hyperplasia 
(Musetti et al. 2016; Zimmermann et al. 2015), phytoplasma infections affect translocation of carbohydrates between source and sink plant organs and alter the metabolic compositions of leaf tissue (Christensen et al. 2005; Lepka et al. 1999; Prezelj et al. 2016). Because phytoplasmas are obligate parasites depending on their host plants and insects, they have small genomes that lack genes for some metabolic pathways and need to obtain nutrients from the host organism (Bai et al. 2006; Kube et al. 2008; Marcone et al. 1996; Marcone et al. 1999). While several studies highlighted changes in the chemistry of plant tissue due to phytoplasma infections, only few studies have determined the effects on the chemical composition of the phloem, which is the side of infection. In the most recent publication comparing the phloem composition of phytoplasma-infected vs. non-infected mulberry plants, Gai et al. (2014) found a change in the metabolic composition of phloem sap in response to phytoplasma infection. Their analysis revealed higher amounts of sucrose, abscisic acid (ABA), cytokinin and total content of free amino acids in phloem sap from infected than non-infected plants. In contrast, the phloem metabolome of coconut palms was not affected by lethal yellowing disease (Stemmer et al. 1982).

' $C a$. P. prunorum' and other phytoplasma species of the $16 \mathrm{SrX}$ or apple proliferation group are transmitted by jumping plant lice or psyllids of the superfamily Psylloidea (Hemiptera: Sternorrhyncha) feeding on plant sieve tube elements (Weintraub and Beanland 2006). These psyllidtransmitted phytoplasmas as well as their vectors are closely related and associated with economically important diseases of fruit trees such as pear decline, apple proliferation and ESFY (Jarausch et al. 2019). The plum psyllid Cacopsylla pruni transmits ' $\mathrm{Ca}$. P. prunorum', the causal agent of ESFY by feeding on the phloem tissue of plants during reproduction (Carraro et al. 1998, 2004b). Little is known about the influence of phytoplasma infections on the nutritional composition of phloem and consequences on vector behavior and development. Amino acid composition, plant defense mechanisms and phytohormone concentrations (Dermastia 2019) could affect insect vector feeding on diseased plants. Although it is well known that nutritional quality and hormonal levels of plants in general impact insect performance and fitness (Cao et al. 2016; Pradit et al. 2019; Schoonhoven et al. 2010; Schweiger et al. 2014), much less is known about how plant infections with phloem-restricted bacteria impact insect fitness.

Cacopsylla picta emigrants that developed on Malus domestica trees infected with ' $\mathrm{Ca}$. P. mali' are smaller and their development is slightly elongated compared to psyllids that develop on healthy apple plants (Mayer et al. 2011). Consequently, females prefer healthy over infected plants for oviposition (Mayer et al. 2011). In contrast, the survival and reproduction of female Macrosteles quadrilineatus and Dalbulus maidis is enhanced on host plants infected with
Aster Yellows-witches' broom phytoplasma (AY-WB) (Beanland et al. 2000; Purcell 1988; Sugio et al. 2011), while the infection of host plants with Bois Noir has no impact on growth of vector progeny (Kaul et al. 2009). By investigating the feeding behavior of Asian citrus psyllid (Diaphorina citri) with electropenetrography (EPG), Cen et al. (2012) recorded lower mean durations of phloem ingestion phase (E2) on plants inoculated with 'Candidatus Liberibacter asiaticus' (CLas) than on uninfected plants. George et al. (2018) revealed lower total durations of E2 per psyllid in infected than uninfected Citrus plants. This reduction of phloem uptake is in accordance with the elongated developmental time of $D$. citri nymphs when reared on CLas-infected compared to uninfected Citrus plants (Pelz-Stelinski et al. 2010).

Prunus persica is highly susceptible to ESFY and shows severe symptoms and high mortality, while $P$. insititia is also susceptible but shows light symptoms and low mortality (Kison and Seemüller 2001). Therefore, we expected a significant influence of ' $\mathrm{Ca}$. P. prunorum' on the phloem metabolome of P. persica. A comparison with the metabolite composition of infected $P$. insititia could indicate whether phloem chemistry is influencing symptom manifestation or reveal components associated with phytoplasma tolerance. Killiny and Hijaz (2016) found higher abundance of amino acids involved in plant defense mechanisms in phloem sap of citrus varieties tolerant to CLas.

To investigate the interaction of ' $\mathrm{Ca}$. P. prunorum' with its natural plant environment, we analyzed sugars, sugar alcohols and organic acids in phloem centrifugates of infected and noninfected Prunus trees. Furthermore, we compared two Prunus species, which were differently affected by the infection (P. persica and P. insititia). To link the composition of primary plant metabolites of phloem centrifugates with vector development, we recorded and analyzed the feeding behavior and development of $\mathrm{C}$. pruni nymphs on healthy and ' $\mathrm{Ca}$. P. prunorum'-infected plants. The importance of volatile organic compounds released by plants on C. pruni host preference and the importance of phloem chemistry on C. pruni development has been addressed previously (Gallinger et al. 2019, Gallinger and Gross 2018). Thus, the objective of the present research was to investigate the importance of gustatory cues on the host plant choice of $C$. pruni using two Prunus species that exhibit different degrees of sensitivity to ESFY phytoplasma infection.

\section{Methods and Materials}

Insects Overwintered C. pruni adults (remigrants) were collected by beating foliage above a collection tray in early spring (March and April). Psyllids were sampled at two different sites: the experimental field and surroundings of the Julius Kühn-Institut (JKI) in Dossenheim, Germany, and an 
experimental Prunus orchard of Dienstleistungszentrum Ländlicher Raum Rheinpfalz (DLR), Neustadt an der Weinstrasse, Germany. Psyllids were reared on Prunus spinosa trees in insect cages (BugDorm, MegaView Science Co, Taiwan $47.5 \times 47.5 \times 93 \mathrm{~cm}$ ), housed in a climate chamber at $20{ }^{\circ} \mathrm{C}$ (photophase) and $16{ }^{\circ} \mathrm{C}$ (scotophase) (L16:D8).

Plants Cultivars of $P$. persica (cv. South Haven) and P. insititia (cv. GF655-2) were used for experiments. P. insititia (cv. GF655-2) plants were dug out in October from the experimental field of the JKI and used for the experiments. Scion wood of P. persica cv. South Haven was grafted on one-yearold peach seedlings (cv. Montclar) as is common practice in fruit growing. All plants were grown in $1.8 \mathrm{~L}$ pots with clay substrate (Klasmann-Dielmann GmbH, Geeste, Germany). Plants were fertilized with $\sim 500 \mathrm{ml}$ Triabon (Compo Expert $\mathrm{GmbH}$, Münster, Germany, $2 \mathrm{~g} / \mathrm{L}$ ) once in March and then weekly with 300-500 mL Wuxal (Hauert MANNA Düngerwerke GmbH, Nürnberg, Germany, 0.2\%). Prunus trees were treated once with paraffin oil in March to prevent infestations with spider mites. All plants were housed in an insect free environment and treated weekly with nematodes Steinernema feltiae (SAUTTER \& STEPPER GmbH, Ammerbuch, Germany) against fungus gnats. Polymerase chain reaction (PCR) analysis revealed naturally occurring phytoplasma infections in P. insititia plants from the field. Because we had no naturally infected $P$. persica plants, $P$. persica trees were graft-inoculated with ' $C a$. P. prunorum' ESFY Q06 from Prunus marianna GF 8-1 (Prunus cerasifera $x$ Prunus munsoniana). Each tree was inoculated with two side-graftings of infected scion wood. Phytoplasma infestation was verified via PCR prior to experiments. Plants that were inoculated but infection with 'Ca. P. prunorum' could not be verified were excluded from the experiments. Experiments were conducted between May and August in 2018 and 2019 during leaf and shoot development. No plants expressed inflorescences during the two years of experiments.

Development of C. pruni The influence of ESFY infection and host species on developmental time of $C$. pruni was investigated. Therefore, nymphs were placed on healthy and ESFYinfected P. persica cv. South Haven and P. insititia cv. GF 655-2 plants. Second instar nymphs were gently transferred with a fine brush from a $P$. spinosa plant to middle-aged fully expanded leaves from experimental plants. Ten nymphs were placed on each leaf and were caged with small gauze bags $(10 \times 12 \mathrm{~cm})$. Due to logistic reasons, seven to ten bags $(70$ 100 nymphs) were attached to plants from each species and ESFY infection status. Bags were monitored daily for nymph development and adult eclosion. Eclosed adults were counted daily and removed from the bags. The experiment continued for 49 days until all adults eclosed or nymphs died. The experiment was set up in May and ended in July 2019. Plants were inoculated with phytoplasmas two years before the experiment.

Electropenetrography (EPG) Fifth instar nymphs were collected from the rearing cages with $P$. spinosa plants one hour before EPG recordings ( $1 \mathrm{~h}$ starvation period). Nymphs were carefully cleaned with a wet cotton stick and were allowed to dry for about $10 \mathrm{~min}$. A droplet of water-based silver glue (EPG-Systems, Wageningen, The Netherlands) was attached to the mesothorax of each nymph and a piece of fine gold wire (18 $\mu \mathrm{m}$ diameter, ca. $1 \mathrm{~cm}$ length) was fixed on the pronotum with a second droplet of silver glue. The gold wire was connected to a copper extension wire soldered to a brass insect pin. The pin was attached to the EPG probe. The reference electrodes were placed into the wet soil of the test plants. The feeding behavior of $C$. pruni nymphs was recorded with an 8channel amplifier (model Giga-8d, EPG-Systems, Wageningen, The Netherlands) in a climate chamber at $23{ }^{\circ} \mathrm{C}$ with $60 \%-65 \% \mathrm{RH}$ for $16 \mathrm{~h}$ (log-day period). Nymphs were placed on the adaxial surface of mature leaves (second to sixth fully expanded leaves). Plants and insects were housed in a grounded self-constructed Faraday cage made of zinc-coated bird cage wire (mesh size: $6.3 \times$ $6.3 \mathrm{~mm}$ ) during the recordings. Feeding patterns of 15 individuals were recorded from both ESFY-infected and noninfected $P$. insititia and P. persica plants. Only recordings from nymphs that showed $16 \mathrm{~h}$ of activity were included in the analysis, while nymphs that molted during the experiment were excluded. EPGs were recorded in May and June one and two years after inoculation with phytoplasmas (2018 and 2019). Data acquisition and analysis was performed with Stylet+ software (EPG-Systems, Wageningen, The Netherlands). Recordings were examined for occurrence of waveforms according to Bonani et al. (2010) and Civolani et al. (2011). Patterns corresponding to the start of penetration and the stylet position in the parenchyma (A, B, C1 and C2) were summarized as intracellular pathway phase (C). The phase between the parenchyma and the phloem was considered at phase D, which has been suggested as the transition phase between parenchyma and phloem. The two phloem feeding waveforms were E1 and E2, while the ingestion of xylem content was G. Finally, the non-probing $(\mathrm{Np})$ phases were also annotated during which time insects were not penetrating the plant tissue with their stylets.

Collection of Sap Samples One phloem sap sample was collected from each tree with the centrifugation technique according to Hijaz and Killiny (2014). Briefly, the bark from young flush of P. persica and P. insititia plants was removed manually and sliced into $1-2 \mathrm{~cm}$ pieces with a clean scalpel. The bottom of a $0.5 \mathrm{ml}$ Eppendorf tube was removed. Each tube was immersed in a second, larger tube $(1.5 \mathrm{ml})$. To collect the phloem content, bark pieces were placed into the small tube 
and centrifuged at $12.000 \mathrm{rpm}$ at $4{ }^{\circ} \mathrm{C}$ for $10 \mathrm{~min}$. The collected samples were stored at $-80^{\circ} \mathrm{C}$ until analysis. As we cannot totally exclude possible slight contamination from mesophyll cell content, we refer to the samples as phloem centrifugates henceforth. Phloem centrifugates were sampled in August 2018 one year after inoculation with phytoplasmas.

Measurement of ${ }^{\circ}$ Brix Value To compare the absolute amount of soluble solid content in phloem centrifugates, ${ }^{\circ}$ Brix values were measured with a handheld refractometer (type 45-81; Bellingham + Stanley Ltd., Tunbridge Wells, UK). The refractometer was calibrated with sucrose as standard. About $1 \mu \mathrm{l}$ phloem centrifugate from either $P$. insititia $\left(\mathrm{n}_{\text {non-infected }}=6, \mathrm{n}\right.$ infected $=6)$ or $P$. persica $\left(\mathrm{n}_{\text {non-infected }}=11, \mathrm{n}_{\text {infected }}=7\right)$ were used for measurements.

Derivatization of Phloem Centrifugates Silylation was used to analyze sugars, sugar derivates and organic acids in phloem centrifugates. Five $\mu \mathrm{l}$ of the samples were added to $60 \mu \mathrm{l}$ of a $1.5 \mathrm{mmol}$ ribitol internal standard solution (Sigma-Aldrich Chemie GmbH, Munich, Germany) and dried under nitrogen stream (Reacti-Vap, Thermo Fisher Scientific Inc., Waltham, Massachusetts, USA). Seventy $\mu$ l of methoxyamine hydrochloride solution (MOX) in pyridine $(2 \%)$ was added to each sample. Methoxyamine was allowed to react for $90 \mathrm{~min}$ at $37{ }^{\circ} \mathrm{C}$ stirring at adjustment of 7 (Reacti-Therm, Thermo Fisher Scientific Inc.). N-methyl-(N-trimethylsilyl) (MSTFA) was used as silylation reagent. After adding $90 \mu \mathrm{l}$ MSTFA to each sample, the reaction was incubated for $60 \mathrm{~min}$ at $37^{\circ} \mathrm{C}$ with stirring at adjustment of 7 . The supernatant was transferred to a GC-MS vial with a glass insert. A second derivatization method using methyl chloroformate was used to optimize the detection of amino acids (Smart et al. 2010). Aliquots of $15 \mu \mathrm{l}$ phloem centrifugates were mixed with $7.5 \mu \mathrm{l}$ DL-norvaline (Sigma-Aldrich Chemie $\mathrm{GmbH}$ ) as an internal standard (17 mmol in ultrapure water) and $180 \mu \mathrm{l}$ sodium hydroxide ( $1 \mathrm{M}) .167 \mu \mathrm{l}$ methanol and $34 \mu$ l pyridine were added, followed by $20 \mu \mathrm{l}$ MCF. Afterwards, the sample was vortexed for $30 \mathrm{~s}$., and an additional $20 \mu \mathrm{l}$ of MCF were added and the sample was mixed for $30 \mathrm{~s}$. again. The alkylated derivatives were extracted by adding $150 \mu \mathrm{l}$ chloroform and mixing for $10 \mathrm{~s}$. After adding a $200 \mu \mathrm{l}$ aliquot of sodium bicarbonate solution $(50 \mathrm{mM})$, the samples were mixed again for 10 s. Silanized glass vials (Carl Roth $\mathrm{GmbH}+\mathrm{Co}$. KG, Karlsruhe, Germany) were used for the chemical reaction. The aqueous phase was discarded. To bind any remaining water, a few milligrams of anhydrous sodium sulfate were added to the organic layer. The supernatant was transferred to a GC-MS vial with a glass insert.

GC-MS Analysis Derivatized samples were analyzed by gas chromatography coupled with mass spectrometry (GCMS) using a PerkinElmer Clarus R 680 GC system coupled to a Perkin Elmer quadrupole inert mass selective detector. For GC separation a nonpolar Elite-5MS (Crossbond 5\% diphenyl $-95 \%$ dimethyl polysiloxane, PerkinElmer) capillary column $(30 \times 0.25 \mathrm{~mm}$ id $\times 0.25 \mu \mathrm{m}$ film thickness $)$ was used. One $\mu$ l of samples derivatized with MCF were injected with an open injector vent at $70{ }^{\circ} \mathrm{C}$ injector temperature, to purge out the solvent. After $0.5 \mathrm{~min}$, the vent was closed and the injector temperature was raised to $290{ }^{\circ} \mathrm{C}$ after $1 \mathrm{~min}$. Carrier gas flow rate (Helium, Air Liquide, Germany) was about $5 \mathrm{ml} / \mathrm{min}$ (column head pressure $130 \mathrm{kPa}$ ) and $30 \mathrm{ml} / \mathrm{min}$ split flow. The initial oven temperature of $80{ }^{\circ} \mathrm{C}$ was held for $2 \mathrm{~min}$, followed by a temperature increase of $10 \mathrm{~K} / \mathrm{min}$ up to $240{ }^{\circ} \mathrm{C}$ held for $3.5 \mathrm{~min}$ and a further increase to $300^{\circ} \mathrm{C}$ at a rate of $20 \mathrm{~K} /$ min. The final temperature of $300{ }^{\circ} \mathrm{C}$ was held for $2 \mathrm{~min}$. For the analysis of sap samples after silylation, $1.5 \mu \mathrm{l}$ of each sample was injected with a split flow of $5 \mathrm{ml} / \mathrm{min}$ at $140{ }^{\circ} \mathrm{C}$ and the injector temperature was increased by $50 \mathrm{~K} /$ min to $250{ }^{\circ} \mathrm{C}$. Column head pressure of Helium flow was set to $130 \mathrm{kPa}$. The $\mathrm{GC}$ temperature program was as follows: the initial oven temperature of $80{ }^{\circ} \mathrm{C}$ was held for $3 \mathrm{~min}$, followed by an increase of $5 \mathrm{~K} / \mathrm{min}$ up to $320^{\circ} \mathrm{C}$. The final temperature of $320^{\circ} \mathrm{C}$ was held for $4 \mathrm{~min}$. For all analysis the transfer line and ion source temperatures were set to $250{ }^{\circ} \mathrm{C}$ and $180{ }^{\circ} \mathrm{C}$ respectively. The quadrupole mass detector was operated in electron-impact (EI) mode at $70 \mathrm{eV}$. All data was obtained by collecting the full-scan mass spectra within the range of $35-550 \mathrm{~m} / \mathrm{z}$. Blank samples, reference standards and mixtures of alkanes (C8 $\mathrm{C} 20$ and $\mathrm{C}$ 10- C40) were analyzed additionally according to both methods. Reference standards and suppliers are listed in the supplementary material (Table S1).

Identification and Quantification with AMDIS Chromatograms of sap sample derivates were analyzed using "Automated Mass spectral Deconvolution and Identification System" (AMDIS, V. 2.71; National Institute of Standards and Technology NIST, Boulder, CO). For the identification, the ion fragmentation patterns and retention indices of detected compounds were compared with standard compounds (Gross et al. 2019). Compounds that were not identified were annotated as unknowns. For quantification, the peak areas were integrated after deconvolution. Identification criteria were applied as follows: match factor had to be $\geq 80 \%$ and the relative retention index deviation $\leq 5 \%$ from reference value. The settings for deconvolution were: component width: 32 ; adjacent peak subtraction: one; resolution: medium; sensitivity: medium; shape requirements: low; level: very strong; maximum penalty: 20 and 'no RI in library': 20. Components with a signal to noise ratio $<50$ were excluded from the analysis. Relative amounts of detected compounds after derivatization were calculated in relation to the respective internal standards norvaline and ribitol. 
Statistical Analyses All statistical analyses were conducted in $\mathrm{R}$ version 3.5.3 (R Core Team 2017). Graphics were produced using the ggplot2 package (Wickham 2009). A parametric survival model (time-to-event analysis) was used to investigate the effect of plant species and the infection status of plants on the development of $C$. pruni. The model was fitted with an exponential distribution with the survreg function of the 'survival' package. Linear models (LMs) were used to determine the influence of the plant species and phytoplasma infection on the duration of waveforms per event (total), duration per nymph (mean) and the time to first occurrence of waveforms in EPG recordings from C. pruni nymphs. In case of non-normality of residuals, the data were transformed as specified in Table S2. The fit of models with the main effects 'Prunus species' and 'ESFY infection status' and the interaction of these two factors was compared by second-order Akaike's information criterion (AICc) corrected for small samples. To analyze the occurrence (frequency) of individual waveforms per nymph, GLMs with quasi-Poisson distribution were used due to overdispersion. To compare models fitted with quasiPoisson distribution the quasi-AICc (qAICc) was computed, using the model deviance instead of the likelihood and used in the ICtab function from 'bbmle' package (Bolker and R Development Core Team 2017). A LM was fitted with square root transformed ${ }^{\circ}$ brix values, to analyze the influence of Prunus species and ESFY infection on the amount of total soluble solid content in phloem centrifugates. AICc was used to identify best model fit. Model assumptions were validated graphically as recommended by Zuur et al. (2009). The emmeans function from the 'emmeans' package (Lenth et al. 2019) was used to calculate the estimated marginal means and corresponding $95 \%$ confidence intervals and to determine differences between treatment levels. In case multiple pairwise comparison $p$-values were adjusted by the method of Tukey. Discrimination of the chemical composition of phloem centrifugates from infected and non-infected Prunus trees was calculated by a type II permutation multivariate analysis of variance (PERMANOVA) of the BrayCurtis dissimilarities matrix. The PERMANOVA was calculated with the adonis.II function from 'RVAideMemoire' package (Hervé 2019). The dispersions of groups were tested for multivariate homogeneity (PERMDISP). Both analyses were calculated with $N=10000$ permutations. The Bray-Curtis dissimilarities were visualized by non-metric multidimensional scaling (NMDS) plots. The scaling was standardized by Wisconsin double standardization and performed using the metaMDS function from 'vegan' package (Oksanen et al. 2019). Influence of main factors and interaction on the relative amount of total amino acids, sugars, sugar alcohols, and organic acids were analyzed by fitting linear models as described above. The model specifications were as reported in Table S3.

\section{Results}

Development of C. pruni After 49 days, all C. pruni nymphs had emerged to adults or died (Fig. 1). The development of C. pruni was significantly different between both Prunus species (survreg, $Z=7.09, d f=1, P<0.01 N=370$ ). Fiftyseven and $60 \%$ of nymphs developed on healthy and phytoplasma-infected $P$. insititia plants, respectively; whereas, $15 \%$ of $C$. pruni emigrants emerged on healthy and $12 \%$ on diseased P. persica trees. Mean development time was 41 and 39 days on healthy and infected P. insititia plants, respectively. On average, $C$. pruni nymphs required 47 days for development on P. persica plants. Phytoplasma infection had no significant influence on the development of $C$. pruni nymphs (survreg, $Z=0.34, d f=1, P=0.73$, $N=370)$.

EPG Waveforms detected in EPG recordings from C. pruni nymphs were comparable to those specified for $C$. pyri (Civolani et al. 2011). The intracellular pathway phase (C), a phase that always occurred between parenchyma and phloem phases (D), two phloem patterns (E1 and E2), a xylem pattern (G) and non-probing phases (Np), as described by Civolani et al. (2011), were identified in the recordings.

Frequency The mean number of waveforms C, E2 and Np phases were neither affected by the Prunus species nor by infection status of the plants. Whereas the main effect of the plant species was significant for the occurrence of waveform $\mathrm{D}\left(G L M, \chi^{2}=9.56, d f=1, P=0.002, N=60\right)$ and $\mathrm{E} 1(G L M$, $\left.\chi^{2}=4.96, d f=1, P=0.026, \mathrm{~N}=60\right)$, both waveforms were recorded more frequently from nymphs feeding on $P$. persica than on $P$. insititia plants (Table 1). The number of bouts of $\mathrm{G}$ was influenced by the infection status of the plants (GLM, $\chi^{2}=4.03, d f=1, P=0.044, N=60$ ). On average, nymphs accessed the xylem of healthy leaves $4 \pm 3.27$ and the xylem of infected leaves $2.7 \pm 1.73$ times during the $16 \mathrm{~h}$ recording period on both Prunus species (Table 1).

Mean Duration Per Psyllid Plant species had a strong effect on the mean duration of $\mathrm{C}$ ( $G L M, F=12.38, d f=1, P=<0.001$, $N=60), \mathrm{D}(G L M, F=11.32, d f=1, P=0.001, \mathrm{~N}=60), \mathrm{E} 1$ $(G L M, F=12.27, d f=1, P=<0.001, \mathrm{~N}=60), \mathrm{E} 2(G L M$, $F=21.80, d f=1, P=<0.001, \mathrm{~N}=60)$ and $\mathrm{Np}(G L M, F=$ 5.75, $d f=1, P=<0.02, \mathrm{~N}=60$ ) phases (Table 2). The mean duration per nymph in the pathway phase and phases $(C)$ of non-probing $(\mathrm{Np})$ were significantly longer during feeding on $P$. persica than on $P$. insititia (Table 2). Furthermore, the durations of $\mathrm{D}$ and $\mathrm{E} 1$ were longer on $P$. persica than $P$. insititia plants (Table 2). Nymphs feeding on P. persica plants spent about $75 \%$ of the time in non-ingestion phases, $13 \%$ ingesting phloem and $9 \%$ ingesting xylem. In contrast, nymphs feeding on $P$. insititia ingested phloem three times longer and the time 
Fig. 1 Cumulative percentage of C. pruni nymphs completing development per day post infestation (dpi) on ESFY infected and healthy $P$. insititia (nhealthy $\left.=100, \mathrm{n}_{\mathrm{ESFY}}=100\right)$ and P. persica $\left(\mathrm{n}_{\text {healthy }}=100, \mathrm{n}_{\mathrm{ESFY}}=\right.$ 70) trees. Ten nymphs were caged together on each leaf

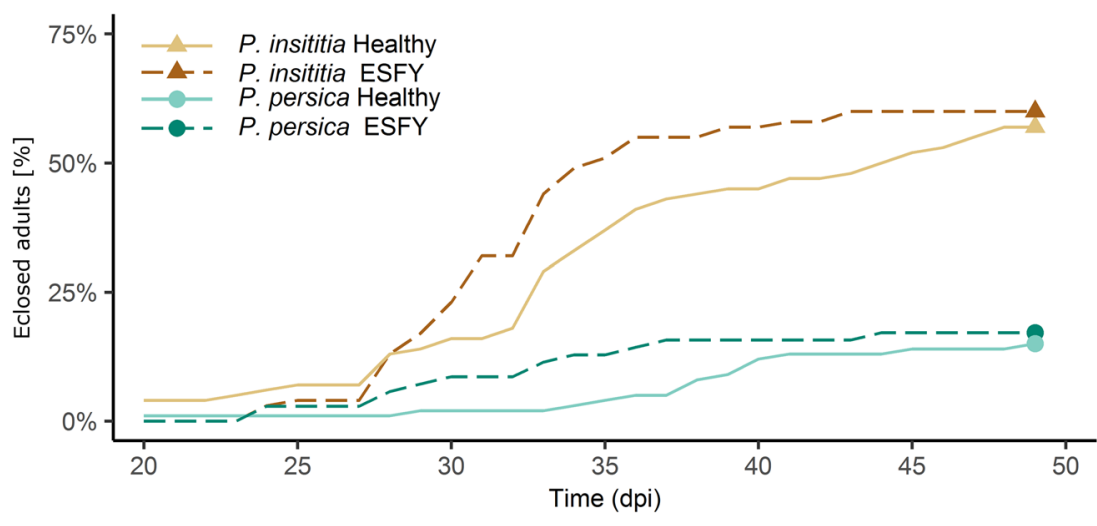

spent in non-feeding phases was $50 \%$ lower than on $P$. persica (Fig. 2b).

Mean Duration Per Event Prunus species and the interaction between species and ESFY infection status significantly affected the mean duration of waveforms not associated with phloem ingestion (C, D, E1 and Np) (Fig.3). C phases were shorter on infected than non-infected $P$. persica trees, whereas infection had no influence on the duration of $\mathrm{C}$ on $P$. insititia plants (Fig. 3). While the duration of E1 and $\mathrm{Np}$ phases was shorter on infected than non-infected $P$. persica plants, E1 and Np lasted longer in infected than in healthy $P$. insititia trees (Fig. 3). Phloem ingestion phases (E2) by nymphs feeding on $P$. insititia were significantly longer than those by nymphs feeding on $P$. persica (Table 3). On average, xylem phases lasted for 22.31 ( $\pm 2.13 \mathrm{SE}$ ) $\mathrm{min}$. The mean duration per event was not affected by Prunus species nor ESFY infection (Table 3).
Time to First Occurrence The time until each waveform occurred the first time was not affected by plant species nor ESFY infection status of the plants (Table S4).

Chemistry of Phloem Centrifugates To estimate the total content of soluble sugar content, ${ }^{\circ}$ Brix was measured from centrifugates. ${ }^{\circ}$ Brix differed significantly as a function of Prunus species ( $L M, F=6.32, d f=1 ; P=0.019, N=30)$. A higher ${ }^{\circ}$ Brix value was measured in centrifugates from $P$. insititia plants $(13.33 \pm 1.76 \mathrm{SD})$ than from $P$. persica plants $(11.33 \pm 2.33 \mathrm{SD})$.

We found 10 amino acids and 9 organic acids (4 unidentified) in phloem centrifugates from Prunus trees after MCF derivatization (Table 4). The chemical composition of amino and organic acid in phloem centrifugates differed between the two Prunus species (Fig. 4a, PERMANOVA, $F=3.97, d f=1, P=0.009, N=34)$. The infection status as well as the interaction between infection and plant species

Table 1 Frequency of waveform events occurring in $16 \mathrm{~h} \mathrm{EPG} \mathrm{recordings} \mathrm{of} \mathrm{C.} \mathrm{pruni} \mathrm{nymphs} \mathrm{on} P$. insititia $\left(\mathrm{n}_{\text {healthy }}=15, \mathrm{n}_{\mathrm{ESFY}}=15\right)$ and $P$. persica $\left(\mathrm{n}_{\text {healthy }}=15, \mathrm{n}_{\mathrm{ESFY}}=15\right)$ trees

\begin{tabular}{|c|c|c|c|c|c|c|c|c|c|c|}
\hline \multicolumn{2}{|c|}{$\begin{array}{l}\text { Waveform } \\
\text { Frequency }\end{array}$} & \multirow{2}{*}{$\begin{array}{l}\text { P. insititia } \\
\text { mean } \pm \mathrm{SE} \\
35.87 \pm 5.3\end{array}$} & \multirow{2}{*}{$\begin{array}{l}(\min -\max ) \\
(5-73)\end{array}$} & \multirow{2}{*}{$\begin{array}{l}\text { P. persica } \\
\text { mean } \pm \mathrm{SE} \\
34.87 \pm 3.06\end{array}$} & \multirow{2}{*}{$\begin{array}{l}(\min -\max ) \\
(20-57)\end{array}$} & \multirow{3}{*}{$\begin{array}{l}\text { P. insititia } \\
\text { emmean (lower-upper } \\
\text { CI) }\end{array}$} & \multirow{3}{*}{$\begin{array}{l}\text { P. persica } \\
\text { emmean (lower-upper } \\
\quad \text { CI) }\end{array}$} & \multirow{3}{*}{$\begin{array}{l}\text { model statistics* } \\
\text { influential } \\
\text { factors }\end{array}$} & \multirow[t]{3}{*}{$\chi^{2}$} & \multirow[t]{3}{*}{$\mathrm{P}$} \\
\hline $\mathrm{C}$ & healthy & & & & & & & & & \\
\hline & ESFY & $33.07 \pm 4.69$ & $(8-65)$ & $39.27 \pm 3.49$ & $(20-58)$ & & & & & \\
\hline \multirow[t]{2}{*}{$\mathrm{D}$} & healthy & $7 \pm 1.75$ & $(1-29)$ & $12.2 \pm 1.27$ & $(3-18)$ & $6.77(5.11-8.97)$ & $11.70(9.45-14.49)$ & species & 9.560 & 0.002 \\
\hline & ESFY & $6.53 \pm 1.06$ & $(1-14)$ & $11.2 \pm 2.15$ & $(0-29)$ & & & & & \\
\hline \multirow[t]{2}{*}{ E1 } & healthy & $11.07 \pm 2.87$ & $(1-48)$ & $16.33 \pm 1.82$ & $(3-27)$ & $10.8(8.16-14.4)$ & $16.3(12.97-20.6$ & species & 4.959 & 0.026 \\
\hline & ESFY & $10.6 \pm 1.8$ & $(1-23)$ & $16.33 \pm 3.16$ & $(0-34)$ & & & & & \\
\hline \multirow[t]{2}{*}{ E2 } & healthy & $6.33 \pm 1.8$ & $(1-30)$ & $8.07 \pm 1.1$ & $(1-16)$ & & & & & \\
\hline & ESFY & $6.53 \pm 1.23$ & $(1-17)$ & $9.2 \pm 2.2$ & $(0-28)$ & & & & & \\
\hline \multirow[t]{2}{*}{ G } & healthy & $3.47 \pm 0.75$ & $(1-13)$ & $4.53 \pm 0.93$ & $(1-15)$ & $4.0(3.13-5.11)$ & & & & \\
\hline & ESFY & $2.2 \pm 0.45$ & $(0-6)$ & $3.2 \pm 0.42$ & $(1-6)$ & $2.7(2.00-3.64)$ & & infection & 4.035 & 0.044 \\
\hline \multirow[t]{2}{*}{$\mathrm{np}$} & healthy & $24.73 \pm 3.66$ & $(3-54)$ & $17.47 \pm 1.94$ & $(4-32)$ & & & & & \\
\hline & ESFY & $23.07 \pm 4.52$ & $(3-62)$ & $24.33 \pm 3.11$ & $(9-50)$ & & & & & \\
\hline
\end{tabular}

Mean $( \pm$ SE) number per nymph, value range of occurrence and significant effects of Prunus species, ESFY infection of Prunus trees on the number of events. The estimated marginal means and the corresponding confidence intervals from the models are shown for significant factors

* Generalized linear models with quasi-Poisson distribution were used to analyze the effects of main factors and interactions on the frequency of waveforms events. Model statistics are presented for models simplified by removing nonsignificant factors due to AICc. 
had no significant effect on the discrimination between the phloem centrifugates (PERMANOVA, infection: $F=1.85$, $d \mathrm{f}=1, P=0.117$, interaction: $F=0.61, d f=1, P=0.647$, $\mathrm{N}=34)$. The variance in samples from $P$. persica was significantly higher than from P. insititia (PERMDISP, $F=17.49$, $d f=1, P=0.0002, \mathrm{~N}=34)$. Higher relative amounts of caffeic acid and one unidentified compound (unknown_RI206) were detected in phloem centrifugates from $P$. insititia plants compared to $P$. persica plants (Table 4). High relative amounts of asparagine, glutamic acid, citric acid and one unknown compound (unknown_RI2062) were found in phloem centrifugates from $P$. persica trees (Table 4). Overall, phloem centrifugates from $P$. persica plants contained higher relative amounts of amino acids than those from P. insititia (Fig. 5).

After TMS derivatization 5 organic acids, 7 sugars and sugar alcohols and 7 unidentified compounds were detected in phloem centrifugates (Table 4). The chemical composition of compounds after silylation differed significantly between the two Prunus species (Fig. 4b, PERMANOVA, $F=23.33$, $d f=1, P=9 \mathrm{e}-05, N=40$ ); whereas, infection with ' $C a$. P. prunorum' had no influence on the composition of the detected metabolites (PERMANOVA, $F=1.11, d f=1, P=0.326$, $\mathrm{N}=40$ ). The variability between all four groups did not differ (PERMDISP, $F=2.723, d f=3, P=0.059, \mathrm{~N}=40$ ). In general, $P$. persica samples showed a greater variance than samples from P. insititia (PERMDISP, $F=4.891, d f=1, P=0.033$, $\mathrm{N}=40$ ). Sorbitol was the most abundant compound in phloem centrifugates from both Prunus species (Table 4). Phloem centrifugates from $P$. insititia contained more sorbitol, sucrose and quinic acid than those from $P$. persica plants (Table 4). However, larger quantities of unknown_RI2519 were detected in samples from P. persica than form P. insititia (Table 4). The relative amount of sugars/sugar alcohols and organic acids was significantly higher in phloem centrifugates from P. insititia than from P. insititia plants (Fig. 5).

\section{Discussion}

It was shown previously that the plum psyllid, C. pruni, prefers $P$. insititia plants over $P$. persica plants in field (Gallinger et al. 2019). Our current results suggest that avoidance of $P$. persica appears to be beneficial to $C$. pruni, given that nymphs feeding on $P$. persica exhibited prolonged developmental time and reduced developmental success than observed on $P$. insititia. In contrast, nymphs seem not to be repelled by $P$. persica plants because they initiated stylet penetration behavior as fast as that observed on $P$. insititia. This is in accordance with recent findings from olfactometer assays, showing that $C$. pruni exhibit no preference between $P$. insititia and P. persica plants based on olfactory cues (Gallinger et al. 2019). Waveform D, as recorded by EPG, is 


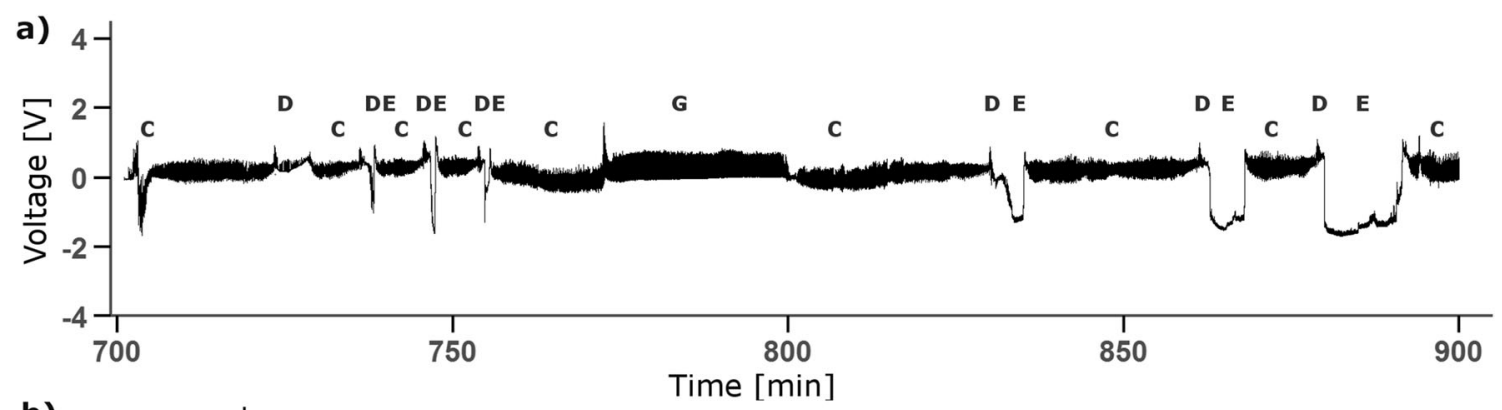

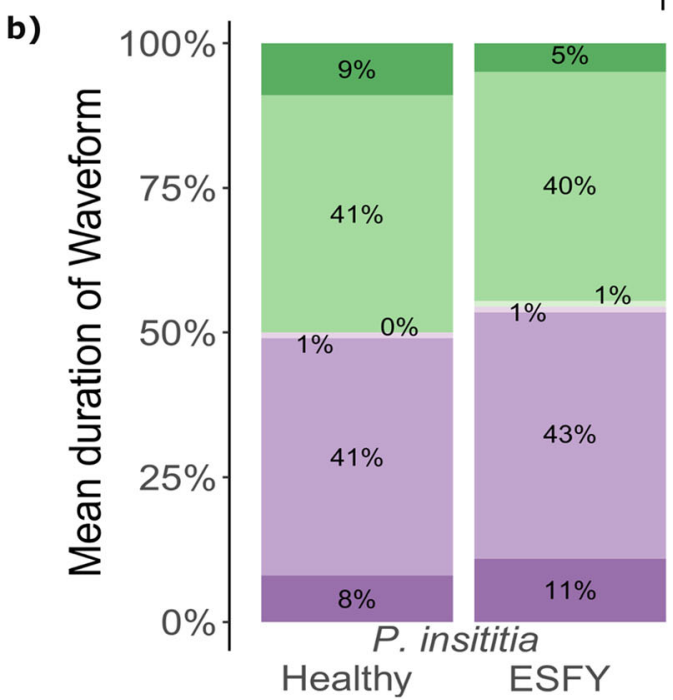

Fig. 2 a) Example of electropenetrography recording from $C$. pruni nymphs on a non-infected $P$. persica plant showing the classified waveforms: Intracellular pathway phase $(\mathrm{C})$, transition phase between the parenchyma and the phloem (D), phloem salvation and ingestion (E), ingestion of xylem content $(\mathrm{G})$ and the non-probing $(\mathrm{Np})$ phases. b) Mean

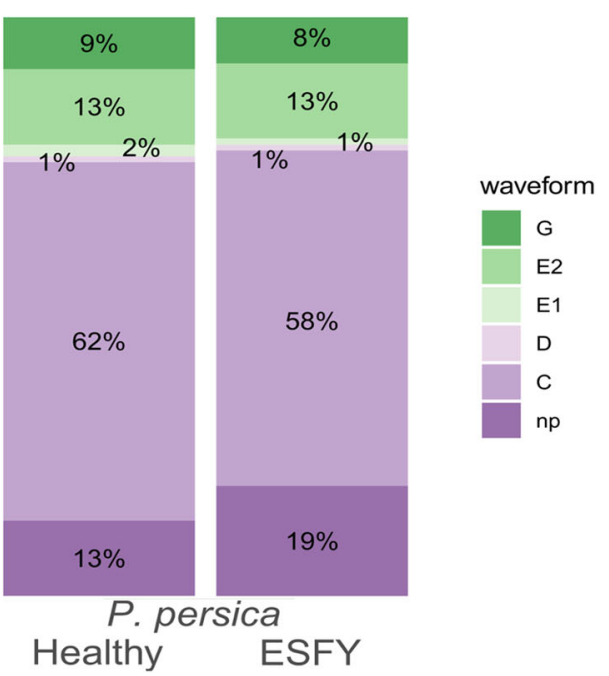

percentage duration of waveforms per psyllid detected during $16 \mathrm{~h}$ EPG recordings with $C$. pruni nymphs on $P$. insititia $\left(\mathrm{n}_{\text {healthy }}=15, \mathrm{n}_{\mathrm{ESFY}}=15\right.$ ) and P. persica $\left(\mathrm{n}_{\text {healthy }}=15, \mathrm{n}_{\mathrm{ESFY}}=15\right)$ trees. Additional explanations to particular waveforms are given in the text thought to reveal the transition from parenchyma to phloem tissue feeding (Civolani et al. 2011). Extended periods in D phase could be a result of structural characteristics of the vascular tissue, but $C$. pruni nymphs were able to reach the phloem of $P$. persica as often and as fast as that of $P$. insititia. Thus, mechanical barriers like sclerenchymatous rings surrounding the phloem, which are shown to inhibit adult $D$. citri from reaching the vascular tissue (Ammar et al. 2014), are unlikely to be involved in this system. Regardless, the duration of phloem-feeding by $C$. pruni was drastically reduced on $P$. persica compared to $P$. insititia plants. Therefore, we suggest that the feeding preference for $P$. insititia may be rather influenced by phloem chemistry than by mechanical barriers.

Analyses of phloem centrifugates revealed significant differences between the chemical composition of P. persica and $P$. insititia. We recorded higher brix values for phloem centrifugates of $P$. insititia than those for $P$. persica. GC-MS analysis revealed higher amounts of sucrose, sorbitol and quinic acid in phloem of $P$. insititia compared to $P$. persica. Although phloem is generally rich in nutrients, amino acids essential for insects are rare and phloem-feeders have to face the challenge of overabundance of carbohydrates and high osmotic pressures comprising their diets (Douglas 2006; Douglas et al. 2006).

In contrast to differences in feeding behavior pattern between the two plant species, phytoplasma infections solely significantly decreased in both Prunus species the duration of xylem ingestion. The same effect of bacterial infection (CLas) of Citrus plants on feeding behavior of D. citri was found using EPG studies (Cen et al. 2012; George et al. 2018). Typically, psyllid nymphs exhibit reduced xylem ingestion and prolonged phloem ingestion compared to adults to meet their nutritional requirements (Civolani et al. 2011; George et al. 2018). Interestingly, in our study the reduction of xylem ingestion was not associated with prolonged phloem ingestion. It is assumed that xylem ingestion by phloem-feeders helps regulate fluid balance (Spiller et al. 1990). For example, potato aphids (Macrosiphum euphorbiae) use ingestion of xylem content to regulate their osmotic potential (Pompon et al. 2011). The higher amount of soluble carbohydrates in $P$. insititia did not lead to an increased ingestion of xylem content by $C$. pruni nymphs feeding on P. insititia. Nymphs spent more time feeding on phloem and their mortality was lower on P. insititia plants, which contained fewer amino acids 
Fig. 3 Interaction plots of estimated marginal means and confidence intervals predicted from linear models of the mean duration per event of the waveform $\mathrm{C}, \mathrm{Np}$ and $\mathrm{E} 1$ from EPG recordings of $C$. pruni nymphs feeding on healthy or ESFY infected $P$. insititia $\left(\mathrm{n}_{\text {healthy }}=15, \mathrm{n}_{\mathrm{ESFY}}=15\right)$ and P. persica $\left(\mathrm{n}_{\text {healthy }}=15, \mathrm{n}_{\mathrm{ESFY}}=\right.$ 15) trees

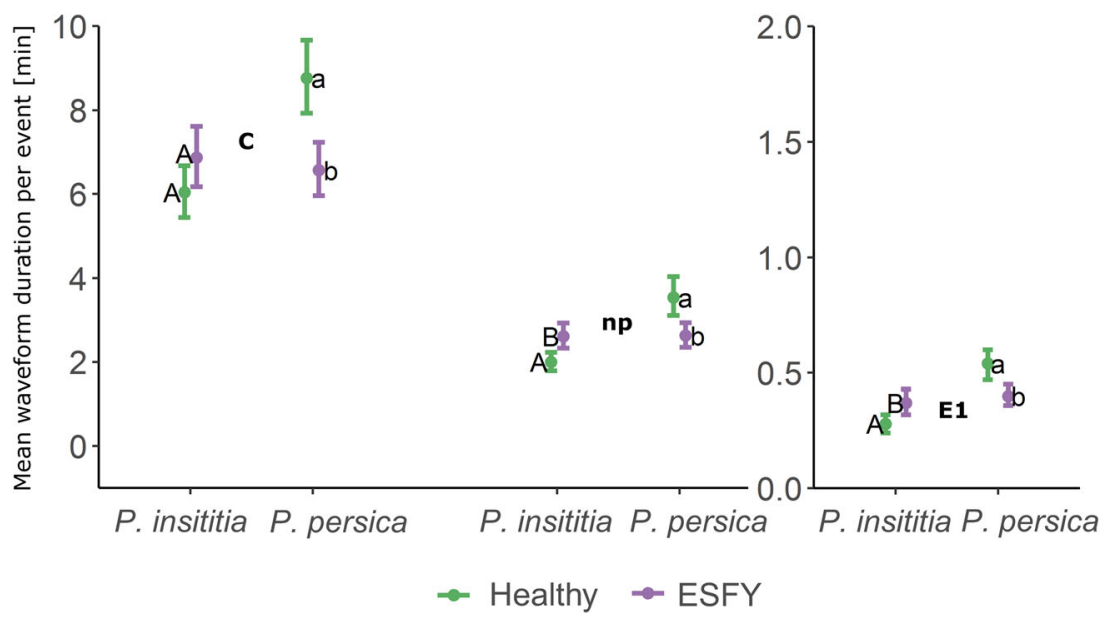

and higher amounts of sugars, than on $P$. persica plants, which had more amino acids and fewer sugars. The observed feeding behavior indicates that $C$. pruni is well adapted to $P$. insititia as a diet. Congruently, Jakobs and Müller (2018) documented that a high abundance of amino acids in phloem does not increase the developmental success of aphids in general. Instead, individual aphid species are adapted to specialized diet compositions (Jakobs et al. 2019). Interestingly, we found no increase in total sugar concentration (Brix value) in infected compared to non-infected plants. Thus, our results suggest that increased xylem phases are independent from phloem conditions and therefore might be based on differences in xylem metabolites.

Sugars can act as feeding stimulants for insects. The best-known example is sucrose, which stimulates feeding of many phytophagous insects, including aphids (Arn and Cleere 1971; Chapman 2003; Mittler and Dadd 1963). The sugar alcohol sorbitol is a characteristic phloem metabolite

Table 3 Duration of waveform per event from $16 \mathrm{~h}$ EPG recordings of $C$. pruni nymphs on $P$. insititia $\left(\mathrm{n}_{\text {healthy }}=15, \mathrm{n}_{\mathrm{ESFY}}=15\right)$ and $P$. persica $\left(\mathrm{n}_{\text {healthy }}=15, \mathrm{n}_{\mathrm{ESFY}}=15\right)$ trees

\begin{tabular}{|c|c|c|c|c|c|c|c|c|c|c|}
\hline \multirow{2}{*}{\multicolumn{2}{|c|}{ 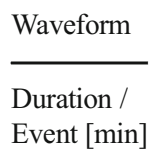 }} & \multicolumn{2}{|l|}{ P. insititia } & \multicolumn{2}{|l|}{ P. persica } & \multirow{2}{*}{$\begin{array}{l}\text { P. insititia } \\
\text { emmean (lower- } \\
\text { upper CI) }\end{array}$} & \multirow{2}{*}{$\begin{array}{l}\text { P. persica } \\
\text { emmean (lower- } \\
\text { upper CI) }\end{array}$} & \multicolumn{3}{|c|}{ model statistics* } \\
\hline & & mean $\pm \mathrm{SE}$ & $(\min -\max )$ & mean $\pm \mathrm{SE}$ & $(\min -\max )$ & & & $\begin{array}{l}\text { influential } \\
\text { factors }\end{array}$ & $\mathrm{F}$ & $\mathrm{P}$ \\
\hline \multirow[t]{3}{*}{$\mathrm{C}$} & healthy & $10.84 \pm 0.67$ & $(0.05-174.54)$ & $16.75 \pm 1.23$ & $(0.04-266.82)$ & $6.04(5.44-6.68)$ & $8.76(7.93-9.67)$ & species & 9.549 & 0.002 \\
\hline & ESFY & $12.39 \pm 0.76$ & $(0.12-130.96)$ & $13.83 \pm 1.23$ & $(0.04-516.39)$ & $6.87(6.18-7.62)$ & $6.57(5.96-7.24)$ & infection & 2.958 & 0.085 \\
\hline & & & & & & & & interaction & 16.448 & $<.001$ \\
\hline \multirow[t]{3}{*}{ D } & healthy & $0.9 \pm 0.06$ & $(0.06-4)$ & $1.15 \pm 0.05$ & $(0.38-5.56)$ & $0.77(0.70-0.85)$ & $1.05(0.97-1.13)$ & species & 20.818 & $<.001$ \\
\hline & ESFY & $0.94 \pm 0.04$ & $(0.14-2.42)$ & $1.08 \pm 0.05$ & $(0.05-5.23)$ & $0.85(0.77-0.94)$ & $0.94(0.87-1.02)$ & infection & 0.487 & 0.486 \\
\hline & & & & & & & & interaction & 5.315 & 0.022 \\
\hline \multirow[t]{3}{*}{ E1 } & healthy & $0.38 \pm 0.03$ & $(0.02-2.22)$ & $1.04 \pm 0.1$ & $(0.05-11.89)$ & $0.28(0.24-0.32)$ & $0.54(0.47-0.60)$ & species & 28.861 & $<.001$ \\
\hline & ESFY & $0.52 \pm 0.05$ & $(0.03-4.41)$ & $0.67 \pm 0.06$ & $(0.03-7.97)$ & $0.37(0.32-0.43)$ & $0.40(0.36-0.45)$ & infection & 0.814 & 0.367 \\
\hline & & & & & & & & interaction & 16.199 & $<.001$ \\
\hline \multirow[t]{2}{*}{ E2 } & healthy & $60.98 \pm 15.21$ & $(0.23-768.65)$ & $15.56 \pm 4.95$ & $(0.21-461.88)$ & $9.17(6.93-12.12)$ & $3.28(2.54-4.25)$ & species & 42.507 & $<.001$ \\
\hline & ESFY & $57.68 \pm 11.99$ & $(0.09-706.66)$ & $13.3 \pm 2.72$ & $(0.15-300.18)$ & $12.53(9.50-16.52)$ & $4.49(3.51-5.74)$ & infection & 4.075 & 0.044 \\
\hline \multirow[t]{2}{*}{ G } & healthy & $25.2 \pm 6.06$ & $(0.15-272.73)$ & $19.61 \pm 2.66$ & $(0.17-142.97)$ & & & & & \\
\hline & ESFY & $23.05 \pm 4.47$ & $(0.71-135.65)$ & $22.52 \pm 3.68$ & $(0.2-146.13)$ & & & & & \\
\hline \multirow[t]{3}{*}{$\mathrm{np}$} & healthy & $3.25 \pm 0.35$ & $(0.05-100.44)$ & $6.83 \pm 0.91$ & $(0.1-201.55)$ & $2.00(1.79-2.23)$ & $3.54(3.11-4.04)$ & species & 20.775 & $<.001$ \\
\hline & ESFY & $4.42 \pm 0.33$ & $(0.08-58.74)$ & $7.4 \pm 1.27$ & $(0.04-282.72)$ & $2.61(2.33-2.93)$ & $2.63(2.35-2.94)$ & infection & 0.017 & 0.8963 \\
\hline & & & & & & & & interaction & 22.568 & $<.001$ \\
\hline
\end{tabular}

Mean ( \pm SE) duration, value range and significant effects of Prunus species, ESFY infection of Prunus trees and their interaction on the duration per event. The estimated marginal means and the corresponding confidence intervals from the models are shown for significant factors

* Linear models were used to analyze the effects of main factors and interactions on the frequency of waveforms events. Model statistics are presented for models simplified by removing nonsignificant factors due to AICc 
Table 4 Mean relative amounts ( $\pm \mathrm{sd}$ ) of compounds detected via GC-MS analysis after derivatization

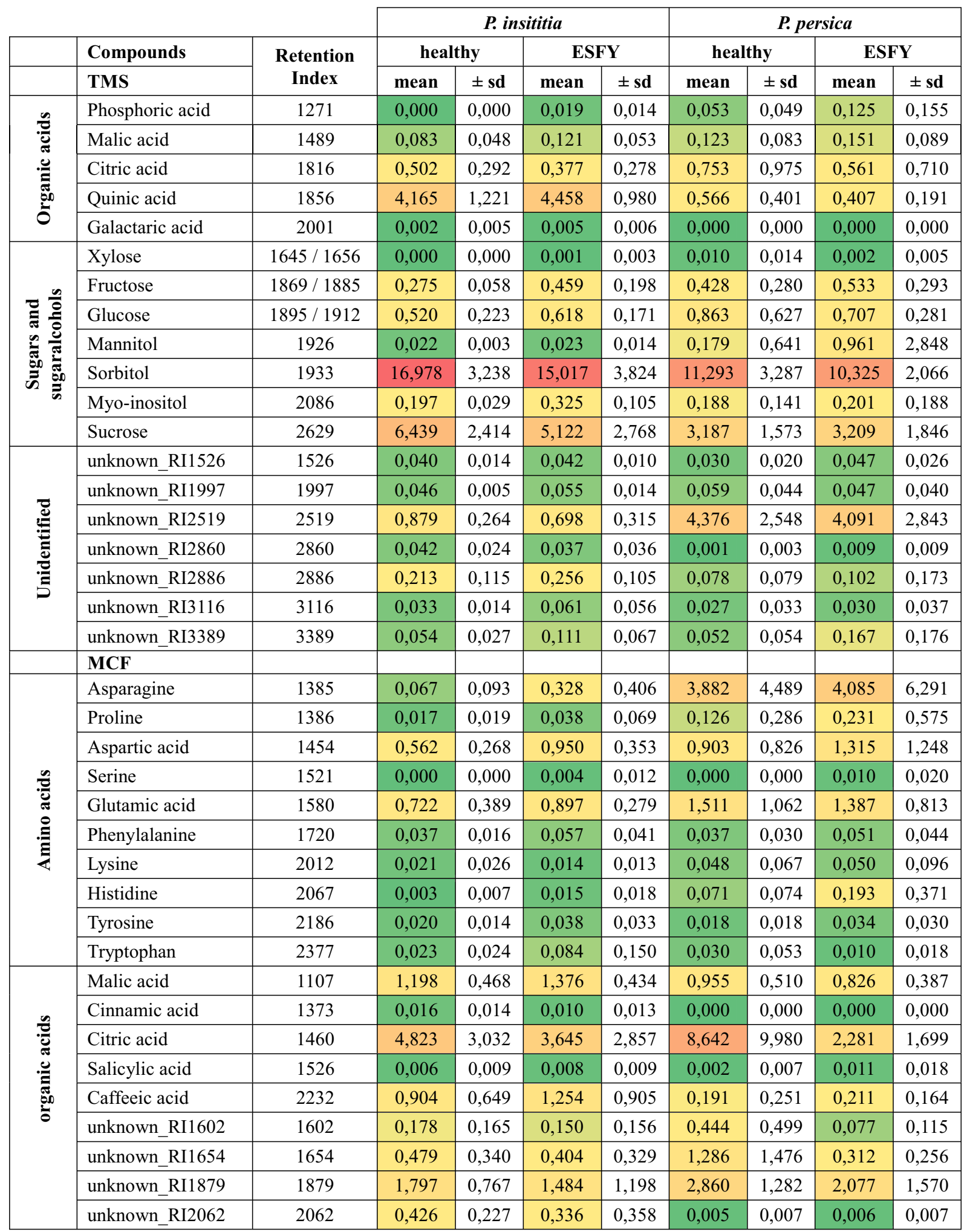

Min

Max

Amounts of organic acids, sugars, sugaralcohols and unknown compounds after silylation of phloem centrifugates from healthy or ESFY infected P. insititia $\left(\mathrm{n}_{\text {healthy }}=6, \mathrm{n}_{\mathrm{ESFY}}=10\right)$ and P. persica $\left(\mathrm{n}_{\text {healthy }}=14, \mathrm{n}_{\mathrm{ESFY}}=10\right)$ trees are relative to internal standard ribitol. Amounts of amino acids and organic acids after MCF derivatization of phloem centrifugates from healthy or ESFY infected $P$. insititia $\left(\mathrm{n}_{\text {healthy }}=5, \mathrm{n}_{\mathrm{ESFY}}=12\right)$ and $P$. persica $\left(\mathrm{n}_{\text {healthy }}=10, \mathrm{n}_{\mathrm{ESFY}}=7\right)$ trees are relative to the internal standard norvaline. Colors range from green (min) to red (max) (see below) 

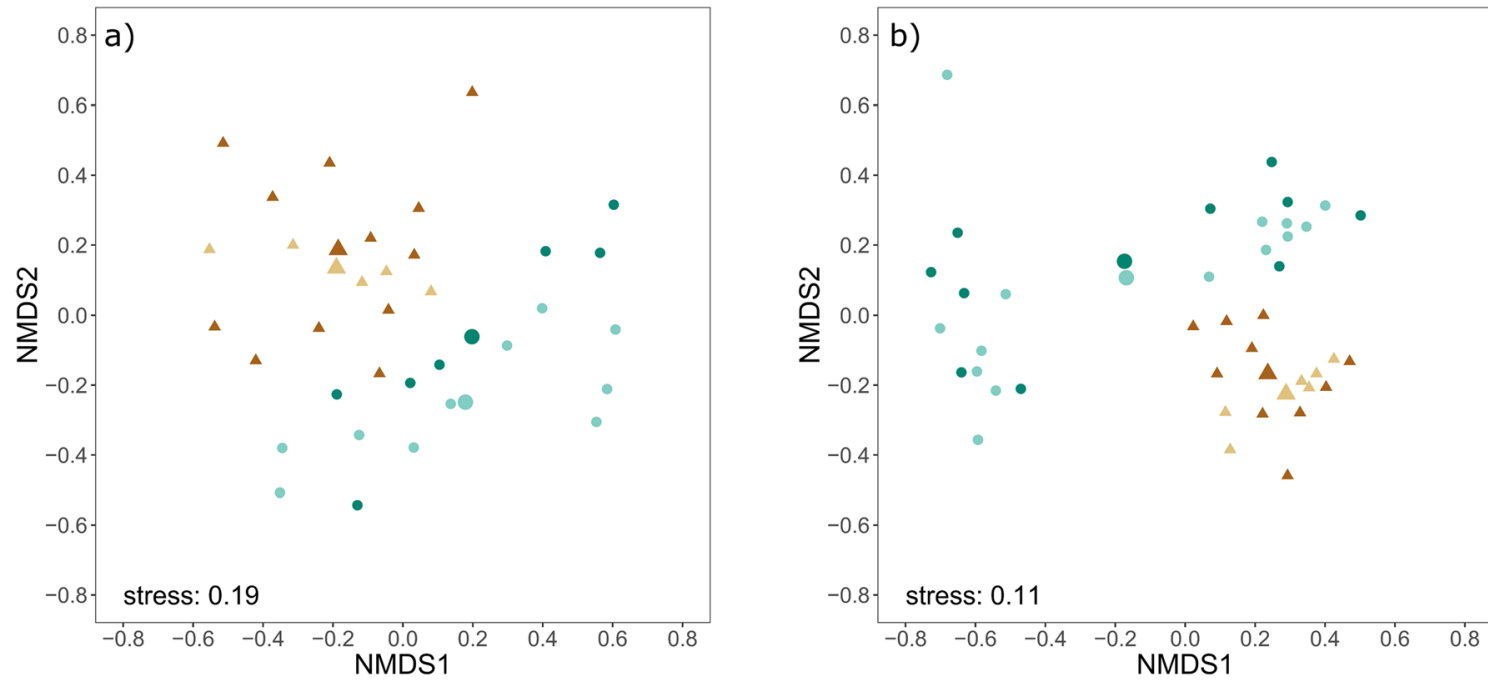

\section{$\triangle P$. insititia Healthy P. persica Healthy \\ $\triangle P$. insititia ESFY O P.persica ESFY}

Fig. 4 Visualization of Bray-Curtis dissimilarities with non-metric multidimensional scaling (NMDS) plots of phloem centrifugates from ESFYinfected (dark) and non-infected (light) Prunus trees. a) amino and other organic acids from $P$. insititia (brown triangles, $\mathrm{n}_{\text {healthy }}=5, \mathrm{n}_{\mathrm{ESFY}}=12$ )

of plants belonging to the Rosaceae and could therefore play a central role in host acceptance of psyllid species feeding on Prunus spp., Malus spp. or Pyrus spp. (Spiraeoideae: Rosaceae). The chemosensory sensilla from the mouthparts of C. pruni have not been described, but phagostimulatory cells that respond to sorbitol are known to occur in caterpillars specialized on rosaceaes plant and $P$. persica (green dots, $\mathrm{n}_{\text {healthy }}=10, \mathrm{n}_{\mathrm{ESFY}}=7$ ) trees and $\mathrm{b}$ ) sugars and organic acids from $P$. insititia ( $\left.\mathrm{n}_{\text {healthy }}=6 \mathrm{n}_{\mathrm{ESFY}}=10\right)$ and $P$. persica $(\mathrm{n}-$ healthy $=14, \mathrm{n}_{\mathrm{ESFY}}=10$ ) trees. Large triangles and circles visualize group centroids

species (Chapman 2003). Although sugars stimulate feeding by herbivores, phloem-feeders must excrete surplus non-assimilated sugars as honeydew (Ammar et al. 2013; Douglas 2006; Le Goff et al. 2019). Thus, future analysis of honeydew from nymphs could reveal components essential for proper development of C. pruni (Le Goff et al. 2019).

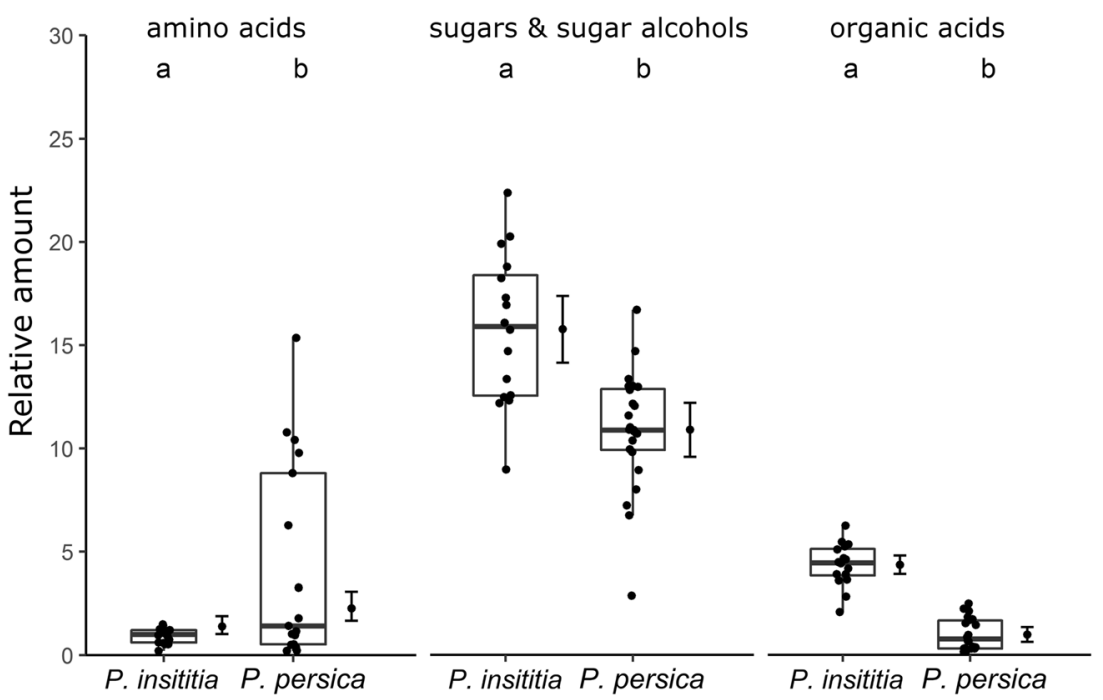

Fig. 5 Mean relative amount of total amino acids of phloem centrifugates from $P$. insititia $(n=17)$ and P. persica $(\mathrm{n}=17)$ after MCF derivatization, sugars and organic acids in phloem centrifugates from $P$. insititia $(n=16)$ and $P$. persica $(n=24)$ after silylation. Amino acids (asparagine, proline, aspartic acid, serine, glutamic acid, phenylalanine, lysine, histidine, tyrosine and tryptophan) have been quantified relative to the internal standard norvaline. Organic acids (phosphoric acid, malic acid, citric acid, quinic acid and galactaric acid), sugars and sugaralcohols (xylose, fructose, glucose, sucrose, mannitol, sorbitol and myo-inositol) after silylation have been quantified relative to internal standard ribitol. Boxes correspond to the 25th and 75th percentiles, medians are shown as lines, and whiskers extend to 1.5 times of the interquartile ranges. Dots represents raw values. Corresponding means and confidence intervals predicted for significant factors from linear models are shown on the right of each box 
Of the compounds detected in the phloem centrifugates (Table 4), caffeic acid is of particular interest. Its possible positive influence on the feeding behavior of $C$. pruni deserves further investigation, because this metabolite was also detected in phloem sap of Prunus domestica but not in conifers, which are no suitable hosts for feeding and development of $C$. pruni's offspring (Gallinger and Gross 2018). Hydroxycinnamic acids are commonly known as constitutive plant defenses against herbivores (Rehman et al. 2012). For example, chlorogenic acid is related to thrips resistance in plants (Leiss et al. 2009; Leiss et al. 2013). To our knowledge, the influence of phenolics on feeding behavior of psyllids has not been studied. Among psyllid species, phagostimulants have only been investigated for $D$. citri and appear to result from degradation products of common citrus volatiles (George et al. 2016; Lapointe et al. 2016). Therefore, further experiments should investigate whether reduced feeding of C. pruni nymphs is based on feeding deterrents or the lack of important metabolites that stimulate feeding on $P$. persica.

In the current study, we investigated the impact of phytoplasma infection on the phloem chemistry of its host plant. For this purpose, we compared two different plant-phytoplasma combinations: a less susceptible Prunus species naturally infected by a 'Ca. P. prunorum' strain, which induced no symptoms, and a highly susceptible Prunus species inoculated with a ' $\mathrm{Ca}$. P. prunorum' isolate that induces characteristic symptoms in the susceptible species. Neither type of infection with either ' $\mathrm{Ca}$. P. prunorum' strain caused major changes in the composition of detected sugars, sugar alcohols and organic acids in P. persica or $P$. insititia plants. Naturally infested $P$. insititia plants were possibly colonized by a different phytoplasma strain than graft-inoculated $P$. persica plants. The virulence of phytoplasmas mainly depends on the combination of scions and isolates, but is also influenced by the rootstock. Kison and Seemüller (2001) investigated the virulence of different ' $C a$. P. prunorum' strains in combination with different Prunus species. P. persica scions and rootstocks suffered from infections with all tested ESFY isolates but to varying degrees. In contrast, $P$. insititia rootstocks have been less susceptible to all tested ESFY isolates. Regarding the current results, we cannot exclude the possibility that other combinations of scions, rootstocks and phytoplasma strains could affect changes to phloem composition. The feeding behavior of $C$. pruni nymphs was partly influenced by phytoplasma colonizing host plants. The interaction of the main factors (Prunus species and ESFY infection) affected feeding behavior. This supports the hypothesis that ESFY infections differentially affect $P$. persica and $P$. insititia trees. Shortened intracellular pathway phases $(\mathrm{C})$ could indicate that $C$. pruni nymphs were able to reach the sieve-tube elements faster on infected $P$. persica than on uninfected plants. This might be a consequence of structural changes in phloem tissue, as enlargement of whole midribs is a characteristic symptom of ESFY in P. persica plants (Marcone et al. 1996).

Indeed, investigations have reported that $C$. pruni can survive and reproduce on $P$. persica in general (Carraro et al. 2004a; Fialová et al. 2004). However, we are the first to show that $P$. persica (peach) is a less suitable host for plum psyllids, which is clearly demonstrated by the low number of nymphs that developed successfully on $P$. persica plants. This is in accordance with findings from field surveys of $C$. pruni feeding on different Prunus species (Carraro et al. 2002; Gallinger et al. 2019; Mergenthaler et al. 2017). The measurement of abundance of $C$. pruni was monitored in these field surveys under the same conditions as in current study: non-grafted $P$. insititia rootstocks were compared with grafted $P$. persica scions on other rootstocks as this is common agricultural practice in fruit growing. To our knowledge there are no studies describing the influence of grafting on phloem chemistry of Prunus species, but it has been shown that rootstock species influences plant growth and fruit quality (Melnyk 2017). The rootstock-scion interaction can also influence psyllid feeding behavior, as grafting on resistant interstocks reduced scion susceptibility to pear psylla, Cacopsylla bidens (ShaltielHarpaz et al. 2018).

Even though P. persica is not a preferred host plant of C. pruni, trees are highly susceptible to phytoplasma infections and suffer from severe symptoms. Manifestation of symptoms could be elicited by physical changes of the vascular system and secondary metabolites, as an infection with $C a$. P. prunorum' induces the release of phytohormones and the deposition of callose in P. persica plants (unpublished data). Phytohormones could affect the feeding behavior of vector nymphs on ESFY-infected $P$. persica trees. There is evidence that plant defense mechanisms mediated by phytohormones are induced in response to ' $\mathrm{Ca}$. P. prunorum' infestations in apricot trees, which may lead to recovery from and tolerance to ESFY (Osler et al. 2014; Osler et al. 2016). Microbial phytopathogens induce hormonal changes in plants both directly and indirectly and this has been demonstrated for bacteria, fungi and viruses (Dermastia 2019; Killiny 2017; Ma and Ma 2016; Mauck et al. 2016). In many pathosystems these modifications are proven to alter the behavior of vector insect either directly or indirectly via volatile organic compounds (Bak et al. 2019; Martini et al. 2017; Martini et al. 2018; Mayer et al. 2008a, 2008b; Rid et al. 2016). Further, the infection status of the vector itself influenced the behavior (Mayer et al. 2008b). In this regard, the feeding and oviposition preferences of adult $C$. pruni, as influenced by their infection status, should be investigated to evaluate the possible effect on the transmission and spread of bacteria. Even though psyllid nymphs are less mobile than winged adults, nymphs spend more time feeding on phloem tissue (E1 and E2) (Civolani et al. 2011; George et al. 2018). As a result, acquisition of bacteria is higher when adults emerge from nymphs 
that fed on infected plants than when uninfected adults feed on infected plants (George et al. 2018; Inoue et al. 2009; PelzStelinski et al. 2010). Consequently, transmission efficiency is higher when bacteria are acquired during the nymph than adult stage (Pelz-Stelinski et al. 2010). Since we found no negative effect of host plant phytoplasma colonization on development of $C$. pruni nymphs, it is possible that emerged adults contained high titers of bacteria and were capable of efficient pathogen inoculation.

Acknowledgments We thank Svenja Stein and Natalie Giesen (JKI, Dossenheim, Germany) for excellent assistance in the lab and Felix Hergenhahn (JKI, Dossenheim, Germany) for cultivation of the plants. We are grateful to Eva Gross (Schriesheim, Germany) and Lukas L. Stelinski (University of Florida, USA) for language editing and helpful comments to an earlier draft of the manuscript.

Author Contributions J Gallinger and J Gross conceived and designed the experiments. J Gallinger conducted the experiments, analyzed the data and wrote the first draft of the manuscript, which was revisited and edited by J Gross. J Gross supervised the project.

Funding Information Open Access funding provided by Projekt DEAL. JGallinger was supported by a fund of the "Landwirtschaftliche Rentenbank" number 28RF4IP008.

\section{Compliance with Ethical Standards}

Conflict of Interest The authors declare that they have no conflict of interest.

Open Access This article is licensed under a Creative Commons Attribution 4.0 International License, which permits use, sharing, adaptation, distribution and reproduction in any medium or format, as long as you give appropriate credit to the original author(s) and the source, provide a link to the Creative Commons licence, and indicate if changes were made. The images or other third party material in this article are included in the article's Creative Commons licence, unless indicated otherwise in a credit line to the material. If material is not included in the article's Creative Commons licence and your intended use is not permitted by statutory regulation or exceeds the permitted use, you will need to obtain permission directly from the copyright holder. To view a copy of this licence, visit http://creativecommons.org/licenses/by/4.0/.

\section{References}

Ammar E-D, Alessandro R, Shatters RG, Hall DG (2013) Behavioral, ultrastructural and chemical studies on the honeydew and waxy secretions by nymphs and adults of the Asian citrus psyllid Diaphorina citri (Hemiptera: Psyllidae). PLoS One 8:e64938. https://doi.org/10.1371/journal.pone.0064938

Ammar E-D, Richardson ML, Abdo Z, Hall DG, Shatters RG (2014) Differences in Stylet sheath occurrence and the fibrous ring (sclerenchyma) between $x$ Citroncirus plants relatively resistant or susceptible to adults of the Asian Citrus Psyllid Diaphorina citri (Hemiptera: Liviidae). PLoS One 9:e110919. https://doi.org/10. 1371/journal.pone.0110919

Arn H, Cleere JS (1971) A double-lable choice-test for the simultaneous determination of diet preference and ingestion by the aphid
Amphorophora agathonica. Entomol Exp Appl 14:377-387. https://doi.org/10.1111/j.1570-7458.1971.tb00175.x

Bai X, Zhang J, Ewing A, Miller SA, Jancso Radek A, Shevchenko DV, Tsukerman K, Walunas T, Lapidus A, Campbell JW, Hogenhout SA (2006) Living with genome instability: the adaptation of phytoplasmas to diverse environments of their insect and plant hosts. J Bacteriol 188:3682-3696. https://doi.org/10.1128/JB.188. 10.3682-3696.2006

Bak A, Patton MF, Perilla-Henao LM, Aegerter BJ, Casteel CL (2019) Ethylene signaling mediates potyvirus spread by aphid vectors. Oecologia 190:139-148. https://doi.org/10.1007/s00442-01904405-0

Beanland L, Hoy CW, Miller SA, Nault LR (2000) Influence of Aster yellows Phytoplasma on the fitness of Aster leafhopper (Homoptera: Cicadellidae). Ann Entomol Soc Am 93:271-276

Bertaccini A, Duduk B, Paltrinieri S, Contaldo N (2014) Phytoplasmas and Phytoplasma diseases: a severe threat to agriculture. Am J Plant Sci 05:1763-1788. https://doi.org/10.4236/ajps.2014.512191

Bolker, B. and R Development Core Team (2017) bbmle: bbmle: Tools for General Maximum Likelihood Estimation. R package version 1.0.20 <https://CRAN.R-project.org/package=bbmle $>$

Bonani JP, Fereres A, Garzo E, Miranda MP, Appezzato-Da-Gloria B, Lopes JRS (2010) Characterization of electrical penetration graphs of the Asian citrus psyllid, Diaphorina citri in sweet orange seedlings. Entomol Exp Appl 134:35-49. https://doi.org/10.1111/j.15707458.2009.00937.x

Cao H-H, Liu H-R, Zhang Z-F, Liu T-X (2016) The green peach aphid Myzus persicae perform better on pre-infested Chinese cabbage Brassica pekinensis by enhancing host plant nutritional quality. Sci Rep 6:21954. https://doi.org/10.1038/srep21954

Carraro L, Ferrini F, Ermacora P, Loi N (2002) Role of wild Prunus species in the epidemiology of European stone fruit yellows. Plant Pathol 51:513-517. https://doi.org/10.1046/j.1365-3059.2002. 00732.x

Carraro L, Ferrini F, Ermacora P, Loi N (2004a) Transmision of European stone fruit yellows Phytoplasma to Prunus species by using vector and graft transmission. Acta Hortic 657:449-453

Carraro L, Ferrini F, Labonne G, Ermacora P, Loi N (2004b) Seasonal infectivity of Cacopsylla pruni, vector of European stone fruit yellows phytoplasma. Ann Appl Biol 144:191-195. https://doi.org/10. 1111/j.1744-7348.2004.tb00333.x

Carraro L, Osler R, Loi N, Ermacora P, Refatti E (1998) Transmission of European stone fruit yellows phytoplasma by Cacopsylla pruni $J$. Plant Pathol 80:233-239. https://doi.org/10.4454/jpp.v80i3.823

Cen Y, Yang C, Holford P, Beattie GAC, Spooner-Hart RN, Liang G, Deng X (2012) Feeding behaviour of the Asiatic citrus psyllid, Diaphorina citri, on healthy and huanglongbing-infected citrus. Entomol Exp Appl 143:13-22. https://doi.org/10.1111/j.15707458.2012.01222.x

Chapman RF (2003) Contact chemoreception in feeding by phytophagous insects. Annu Rev Entomol 48:455-484. https://doi.org/10. 1146/annurev.ento.48.091801.112629

Christensen NM, Axelsen KB, Nicolaisen M, Schulz A (2005) Phytoplasmas and their interactions with hosts. Trends Plant Sci 10:526-535. https://doi.org/10.1016/j.tplants.2005.09.008

Civolani S, Leis M, Grandi G, Garzo E, Pasqualini E, Musacchi S, Chicca M, Castaldelli G, Rossi R, Tjallingii WF (2011) Stylet penetration of Cacopsylla pyri; an electrical penetration graph (EPG) study. J Insect Physiol 57:1407-1419. https://doi.org/10.1016/j.jinsphys. 2011.07.008

Dermastia M (2019) Plant hormones in phytoplasma infected plants. Front Plant Sci 10:477. https://doi.org/10.3389/fpls.2019.00477

Douglas AE (2006) Phloem-sap feeding by animals: problems and solutions. J Exp Bot 57:747-754. https://doi.org/10.1093/jxb/erj067

Douglas AE, Price DRG, Minto LB, Jones E, Pescod KV, François CLMJ, Pritchard J, Boonham N (2006) Sweet problems: insect traits 
defining the limits to dietary sugar utilisation by the pea aphid, Acyrthosiphon pisum. J Exp Biol 209:1395-1403. https://doi.org/ 10.1242/jeb.02148

Fialová R, Navrátil M, Válová $\mathrm{P}$, Lauterer $\mathrm{P}$, Kocourek F, Poncarová-Voráčková Z (2004) Epidemiology of European stone fruit yellows phytoplasma in the Czech Republic. Acta Hortic:483-487. https://doi.org/10.17660/ActaHortic. 2004.657.78

Gai Y-P, Han X-J, Li Y-Q, Yuan C-Z, Mo Y-Y, Guo F-Y, Liu Q-X, Ji X-L (2014) Metabolomic analysis reveals the potential metabolites and pathogenesis involved in mulberry yellow dwarf disease. Plant Cell Environ 37:1474-1490. https://doi.org/10.1111/pce.12255

Gallinger J, Gross J (2018) Unraveling the host plant alternation of Cacopsylla pruni - adults but not nymphs can survive on conifers due to phloem/xylem composition. Front Plant Sci 9:686. https:// doi.org/10.3389/fpls.2018.00484

Gallinger J, Jarausch B, Jarausch W, Gross J (2019) Host plant preferences and detection of host plant volatiles of the migrating psyllid species Cacopsylla pruni, the vector of European stone fruit yellows. J Pest Sci 7:5639-5615. https://doi.org/10.1007/s10340-01901135-3

George J, Ammar E-D, Hall DG, Shatters RG, Lapointe SL (2018) Prolonged phloem ingestion by Diaphorina citri nymphs compared to adults is correlated with increased acquisition of citrus greening pathogen. Sci Rep 8:10352. https://doi.org/10.1038/s41598-01828442-6

George J, Robbins PS, Alessandro RT, Stelinski LL, Lapointe SL (2016) Formic and acetic acids in degradation products of plant volatiles elicit olfactory and behavioral responses from an insect vector. Chem Senses 41:325-338. https://doi.org/10. 1093/chemse/bjw005

Gross J, Gallinger J, Rid M (2019) Collection, identification, and statistical analysis of volatile organic compound patterns emitted by Phytoplasma infected plants. In: Musetti R, Pagliari L (eds) Phytoplasmas: methods and protocols. Humana Press, New York

Hervé, M. (2019) RVAideMemoire: testing and plotting procedures for biostatistics. R package version 0.9-73 https://CRAN.R-project.org/ package $=$ RVAideMemoire

Hijaz F, Killiny N (2014) Collection and chemical composition of phloem sap from Citrus sinensis L. Osbeck (sweet orange). PLoS One 9: e101830. https://doi.org/10.1371/journal.pone.0101830

Inoue $\mathrm{H}$, Ohnishi $\mathrm{J}$, Ito $\mathrm{T}$, Tomimura $\mathrm{K}$, Miyata $\mathrm{S}$, Iwanami $\mathrm{T}$, Ashihara W (2009) Enhanced proliferation and efficient transmission of Candidatus Liberibacter asiaticus by adult Diaphorina citri after acquisition feeding in the nymphal stage. Ann Appl Biol 155:29-36. https://doi.org/10.1111/j. 1744-7348.2009.00317.x

Jakobs R, Müller C (2018) Effects of intraspecific and intra-individual differences in plant quality on preference and performance of monophagous aphid species. Oecologia 186:173-184. https://doi.org/ 10.1007/s00442-017-3998-x

Jakobs R, Schweiger R, Müller C (2019) Aphid infestation leads to plant part-specific changes in phloem sap chemistry, which may indicate niche construction. New Phytol 221:503-514. https://doi.org/10. 1111/nph.15335

Jarausch B, Tedeschi R, Sauvion N, Gross J, Jarausch W (2019) Psyllid vectors. In: Bertaccini A, Weintraub PG, Rao GP, Mori N (eds) Phytoplasmas: plant pathogenic Bacteria - II. Springer Singapore, Singapore, pp 53-78

Jarausch W, Saillard C, Broquaire JM, Garnier M, Dosba F (2000) PCRRFLP and sequence analysis of a non-ribosomal fragment for genetic characterization of European stone fruit yellows phytoplasmas infecting various Prunus species. Mol Cell Probes 14:171-179. https://doi.org/10.1006/mcpr.2000.0304
Kaul C, Seitz A, Maixner M, Johannesen J (2009) Infection of bois-noir tuf-type-I stolbur phytoplasma in Hyalesthes obsoletus (Hemiptera: Cixiidae) larvae and influence on larval size. J Appl Entomol 133: 596-601. https://doi.org/10.1111/j.1439-0418.2009.01406.x

Killiny N (2017) Metabolite signature of the phloem sap of fourteen citrus varieties with different degrees of tolerance to Candidatus Liberibacter asiaticus. Physiol Mol Plant Pathol 97:20-29. https:// doi.org/10.1016/j.pmpp.2016.11.004

Killiny N, Hijaz F (2016) Amino acids implicated in plant defense are higher in Candidatus Liberibacter asiaticus-tolerant citrus varieties. Plant Signal Behav 11:e1171449. https://doi.org/10.1080/ 15592324.2016.1171449

Kison H, Seemüller E (2001) Differences in strain virulence of the European stone fruit yellows Phytoplasma and susceptibility of stone fruit trees on various rootstocks to this pathogen. J Phytopathol 149:533-541

Koncz L, Petróczy M, Ladányi M, Maitz M, NAGY G (2017) Severity of symptoms of European stone fruit yellows on different apricot varieties. Review on Agriculture and Rural Development:63-70

Kube M, Schneider B, Kuhl H, Dandekar T, Heitmann K, Migdoll AM, Reinhardt R, Seemüller E (2008) The linear chromosome of the plant-pathogenic mycoplasma 'Candidatus Phytoplasma Mali'. BMC Genomics 9:306. https://doi.org/ 10.1186/1471-2164-9-306

Lapointe SL, Hall DG, George J (2016) A Phagostimulant blend for the Asian Citrus Psyllid. J Chem Ecol 42:941-951. https://doi.org/10. 1007/s10886-016-0745-4

Le Goff GJ, Lebbe O, Lohaus G, Richels A, Jacquet N, Byttebier V, Hance T (2019) What are the nutritional needs of the pear psylla Cacopsylla pyri? Arthropod Plant Interact 13:431-439. https://doi. org/10.1007/s11829-018-9644-7

Leiss KA, Cristofori G, van Steenis R, Verpoorte R, Klinkhamer PGL (2013) An eco-metabolomic study of host plant resistance to Western flower thrips in cultivated, biofortified and wild carrots. Phytochemistry 93:63-70. https://doi.org/10.1016/j.phytochem. 2013.03.011

Leiss KA, Maltese F, Choi YH, Verpoorte R, Klinkhamer PGL (2009) Identification of chlorogenic acid as a resistance factor for thrips in chrysanthemum. Plant Physiol 150:1567-1575. https://doi.org/10. 1104/pp.109.138131

Lenth, R., Singmann, H., Love, J., Buerkner, P., and Hervé, M. (2019) Estimated marginal means, aka least-squares means. R package version 1.3.5 https://github.com/rvlenth/emmeans

Lepka P, Stitt M, Moll E, Seemüller E (1999) Effect of phytoplasmal infection on concentration and translocation of carbohydrates and amino acids in periwinkle and tobacco. Physiol Mol Plant Pathol 55: $59-68$

Ma K-W, Ma W (2016) Phytohormone pathways as targets of pathogens to facilitate infection. Plant Mol Biol 91:713-725. https://doi.org/10. 1007/s11103-016-0452-0

Marcone C, Neimark H, Ragozzino A, Lauer U, Seemüller E (1999) Chromosome sizes of phytoplasmas composing major phylogenetic groups and subgroups. Phytopathology 89:805810. https://doi.org/10.1094/PHYTO.1999.89.9.805

Marcone C, Ragozzino A, Seemüller E (1996) European stone fruit yellows Phytoplasma as the cause of peach vein enlargement and other yellows and decline diseases of stone fruits in southern Italy. J Phytopathol 144:559-564

Martini X, Coy M, Kuhns E, Stelinski LL (2018) Temporal decline in pathogen-mediated release of methyl salicylate associated with decreasing vector preference for infected over uninfected plants. Front Ecol Evol 6:78. https://doi.org/10.3389/fevo.2018.00185

Martini X, Hughes MA, Killiny N, George J, Lapointe SL, Smith JA, Stelinski LL (2017) The fungus Raffaelea lauricola modifies behavior of its Symbiont and vector, the Redbay Ambrosia beetle 
(Xyleborus Glabratus), by altering host plant volatile production. J Chem Ecol 43:519-531. https://doi.org/10.1007/s10886-017-0843-

Mauck KE, de Moraes CM, Mescher MC (2016) Effects of pathogens on sensory-mediated interactions between plants and insect vectors. Curr Opin Plant Biol 32:53-61. https://doi.org/10.1016/j.pbi.2016. 06.012

Mayer CJ, Vilcinskas A, Gross J (2008a) Pathogen-induced release of plant allomone manipulates vector insect behavior. J Chem Ecol 34: 1518-1522. https://doi.org/10.1007/s10886-008-9564-6

Mayer CJ, Vilcinskas A, Gross J (2008b) Phytopathogen lures its insect vector by altering host plant odor. J Chem Ecol 34:1045-1049. https://doi.org/10.1007/s10886-008-9516-1

Mayer CJ, Vilcinskas A, Gross J (2011) Chemically mediated multitrophic interactions in a plant-insect vector-phytoplasma system compared with a partially nonvector species. Agric For Entomol 13:25-35. https://doi.org/10.1111/j.1461-9563.2010.00495.x

Melnyk CW (2017) Plant grafting: insights into tissue regeneration. Regeneration 4:3-14. https://doi.org/10.1002/reg2.71

Mergenthaler E, Kiss B, Kiss E, Viczián O (2017) Survey on the occurrence and infection status of Cacopsylla pruni, vector of European stone fruit yellows in Hungary. Bull Insectology 70:171-176

Mittler TE, Dadd RH (1963) Studies on the artificial feeding of the aphid Myzus persicae (Sulzer): I. relative uptake of water and sucrose solutions. J Insect Physiol 9:623-645

Musetti R, Pagliari L, Buxa SV, Degola F, de Marco F, Loschi A, Kogel K-H, van Bel AJE (2016) OHMS**: Phytoplasmas dictate changes in sieve-element ultrastructure to accommodate their requirements for nutrition, multiplication and translocation. Plant Signal Behav 11:e1138191. https://doi.org/10.1080/15592324.2016.1138191

Nečas T, Kiss T, Eichmeier A, Nečasová J, Ondrášek I (2017) The effect of Phytoplasma disease caused by 'Candidatus Phytoplasma prunorum' on the Phenological and Pomological traits in apricot trees. Not Bot Horti Agrobot Cluj Napoca 46:107. https://doi.org/ $10.15835 /$ nbha46110879

Oksanen J, Blanchet FG, Friendly M, Kindt R, Legendre P, McGlinn D, Minchin PR, O'Hara RB, Simpson GL, Solymos P, Henry M, Stevens H, Szoecs E, Wagner H (2019) Vegan: community ecology package. R package version 2.5-5 https://cran.r-project.org, https://github.com/vegandevs/vegan

Osler R, Borselli S, Ermacora P, Ferrini F, Loschi A, Martini M, Moruzzi S, Musetti R, Giannini M, Serra S, Loi N (2016) Transmissible tolerance to European stone fruit yellows (ESFY) in apricot: crossprotection or a plant mediated process? Phytoparasitica 44:203-211. https://doi.org/10.1007/s12600-016-0509-2

Osler R, Borselli S, Ermacora P, Loschi A, Martini M, Musetti R, Loi N (2014) Acquired tolerance in apricot plants that stably recovered from European stone fruit yellows. Plant Dis 98:492-496. https:// doi.org/10.1094/PDIS-03-13-0342-RE

Pelz-Stelinski KS, Brlansky RH, Ebert TA, Rogers ME (2010) Transmission parameters for Candidatus liberibacter asiaticus by Asian citrus psyllid (Hemiptera: Psyllidae). J Econ Entomol 103: 1531-1541. https://doi.org/10.1603/EC10123

Pompon J, Quiring D, Goyer C, Giordanengo P, Pelletier Y (2011) A phloem-sap feeder mixes phloem and xylem sap to regulate osmotic potential. J Insect Physiol 57:1317-1322. https://doi.org/10.1016/j. jinsphys.2011.06.007

Pradit N, Mescher MC, Wang Y, Vorsa N, Rodriguez-Saona C (2019) Phytoplasma infection of cranberries benefits non-vector Phytophagous insects. Front Ecol Evol 7:418. https://doi.org/10. 3389/fevo.2019.00181

Prezelj N, Covington E, Roitsch T, Gruden K, Fragner L, Weckwerth W, Chersicola M, Vodopivec M, Dermastia M (2016) Metabolic consequences of infection of grapevine (Vitis vinifera L.) cv. "Modra frankinja" with Flavescence Dorée Phytoplasma. Front Plant Sci 7: 711. https://doi.org/10.3389/fpls.2016.00711
Purcell AH (1988) Increased survival of Dalbulus maidis, a specialist on maize, on non-host plants infected with mollicute plant pathogens. Entomol Exp Appl 46:187-196. https://doi.org/10.1111/j.15707458.1988.tb01110.x

R Core Team (2017) R: a language and environment for statistical computing: R Foundation for statistical computing, Vienna, Austria https://www.R-project.org/

Rehman F, Kahn FA, Badruddin SMA (2012) Role of Phenolics in plant defense against insect Herbivory. In: Khemani LD, Srivastava MM, Srivastava S (eds) Chemistry of Phytopotentials: Health, Energy and Environmental Perspectives. Springer Berlin Heidelberg, Berlin, Heidelberg, pp 309-313

Richter S (2002) Susceptibility of Austrian apricot and peach cultivars to ESFY. Plant Prot Sci 38:281-284

Rid M, Mesca C, Ayasse M, Gross J (2016) Apple proliferation Phytoplasma influences the pattern of plant volatiles emitted depending on pathogen virulence. Front Ecol Evol 3:271. https://doi. org/10.3389/fevo.2015.00152

Schoonhoven LM, van Loon JJA, Dicke M (2010) Insect-plant biology, 2nd edn. Oxford biology: Oxford Univ. Press, Oxford

Schweiger R, Heise A-M, Persicke M, Müller C (2014) Interactions between the jasmonic and salicylic acid pathway modulate the plant metabolome and affect herbivores of different feeding types. Plant Cell Environ 37:1574-1585. https://doi.org/10.1111/pce.12257

Shaltiel-Harpaz L, Gerchman Y, Ibdah M, Kedoshim R, Rachmany D, Hatib K, Bar-Ya'akov I, Soroker V, Holland D (2018) Grafting on resistant interstocks reduces scion susceptibility to pear psylla. Cacopsylla bidens Pest Manag Sci 74:617-626. https://doi.org/10. $1002 /$ ps. 4745

Smart KF, Aggio RBM, Van Houtte JR, Villas-Bôas SG, (2010) Analytical platform for metabolome analysis of microbial cells using methyl chloroformate derivatization followed by gas chromatography-mass spectrometry. Nature Protocols 5 (10): 1709-1729

Smith IM (1997) Quarantine pests of Europe: data sheets on quarantine pests for the European Communities and for the European and Mediterranean plant protection organization: $\mathrm{CAB}$ international in association with the European and Mediterranean plant protection organization, Wallingford

Spiller NJ, Koenders L, Tjallingii WF (1990) Xylem ingestion by aphids a strategy for maintaining water balance. Entomol Exp Appl 55: 101-104. https://doi.org/10.1111/j.1570-7458.1990.tb01352.x

Stemmer WPC, Archer DB, Daniels MJ, Davies AMC, Eden-Green SJ (1982) Effects of lethal yellowing on the composition of the phloem sap from coconut palms in Jamaica. Phytopathology 72:672-675

Sugio A, Kingdom HN, MacLean AM, Grieve VM, Hogenhout SA (2011) Phytoplasma protein effector SAP11 enhances insect vector reproduction by manipulating plant development and defense hormone biosynthesis. Proc Natl Acad Sci U S A 108:E1254-E1263. https://doi.org/10.1073/pnas.1105664108

Torres E, Martin MP, Paltrinieri S, Vila A, Masalles R, Bertaccini A (2004) Spreading of ESFY Phytoplasmas in stone fruit in Catalonia (Spain). J Phytopathol 152:432-437

Weintraub PG, Beanland L (2006) Insect vectors of phytoplasmas. Annu Rev Entomol 51:91-111. https://doi.org/10.1146/annurev.ento.51. 110104.151039

Wickham H (2009) ggplot2: elegant graphics for data analysis. Use R: Springer-Verlag New York, New York

Zimmermann MR, Schneider B, Mithöfer A, Reichelt M, Seemüller E, Furch ACU (2015) Implications of Candidatus Phytoplasma Mali infection on phloem function of apple trees. Endocytobiosis Cell Res 26:67-75

Zuur AF, Ieno EN, Walker N, Saveliev AA, Smith GM (2009) Mixed effects models and extensions in ecology with R: Springer New York, New York 